\title{
Culture-led regeneration as a vital instrument for preserving the cultural heritage of historical parks in Poland
}

\author{
Stefania Środa-Murawska - Elżbieta Grzelak-Kostulska - Leszek S. Dąbrowski \\ - Jadwiga Biegańska - Paweł Smoliński
}

Stefania Środa-Murawska, $\mathrm{PhD}^{1}$

Nicolaus Copernicus University in Toruń, Poland

Faculty of Earth Sciences and Spatial Management

e-mail: steffi@umk.pl

ORCID: 0000-0002-2357-2613

Prof. Elżbieta Grzelak-Kostulska

Nicolaus Copernicus University in Torun, Poland

Faculty of Earth Sciences and Spatial Management

e-mail: grzelak@umk.pl

ORCID: 0000-0002-5797-9366

Leszek S. Dabrowski, MSc

Nicolaus Copernicus University in Torun, Poland

Interdisciplinary Doctoral School of Social Sciences

e-mail: 1.dabrowski@doktorant.umk.pl

ORCID: 0000-0002-7671-1242

Prof. Jadwiga Biegańska

Nicolaus Copernicus University in Toruń, Poland

Faculty of Earth Sciences and Spatial Management

e-mail: jadwigab@umk.pl

ORCID: 0000-0002-0586-089X

Paweł Smoliński, MSc

Nicolaus Copernicus University in Torun, Poland

Interdisciplinary Doctoral School of Social Sciences

e-mail: p.smolinski@doktorant.umk.pl

ORCID: 0000-0003-2643-5240

DOI: $10.46284 / \mathrm{mkd} .2021 .9 .1 .3$

Culture-led regeneration as a vital instrument for preserving the cultural heritage of historical parks in Poland Historical parks and palace and park complexes deserve special protection for their potential and as the embodiment of national heritage. Most of them are impressive estates that bear witness to their times and reflect the dreams and aspirations of their owners. However, because of the entangled history of post-socialist countries including Poland much of the cultural heritage they represent has been irreversibly destroyed.

The aim of the study was to assess the concept of culture-led regeneration as applied to palace and park complexes situated in rural areas at risk of marginalisation in a post-socialist country, Poland, using the case of Kujawsko-Pomorskie Voivodeship. Its findings show that culture-led regeneration is a valuable instrument for protecting historical palace and park estates, which saves the areas from further devastation and boosts local development.

Keywords: palace and park complexes, post-socialist country, Poland, culture-led regeneratio

${ }^{1}$ corresponding author 
S. Środa-Murawska et al.: Culture-led regeneration as a vital instrument for preserving the cultural heritage...

\section{Introduction}

Historical parks and palace and park complexes (PPCs) deserve special protection because of their potential and as heritage assets. Most of them are impressive estates that bear witness to their times and embody the dreams and aspirations of their past owners. The most renowned of them, such as the Palace of Versailles and the Peterhof Palace, are "must-see destinations" for contemporary tourists that are carefully maintained and protected. ${ }^{2}$ Unfortunately, many of the less impressive and frequently unknown historical PPCs situated in rural areas are falling into disrepair, to eventually disappear altogether.

Particularly in Central and Eastern European countries, there are many examples of this type of once important, forgotten objects located outside major cities, such as old railroad stations or public buildings (e.g. hospitals) that have been put out of use. These objects, such as former border railway stations in Poland, are often visually and functionally significant public space elements, and thus are an important part of the cultural environment. ${ }^{3}$ With their presence, they often become silent witnesses of the social, economic, and cultural history of a given region. One such example is the old hospital in Topol'čany considered by Tišliar et al. in the context of its historical and ethnological links within an urban environment. ${ }^{4}$ Such facilities are frequently the furthest destinations from major tourist regions. ${ }^{5}$ Therefore, it is difficult to expect tangible economic effects associated with the development of tourism based on this forgotten heritage. Nevertheless, observing trends in tourism development, it can be assumed that if certain conditions are met, despite difficulties in their transport accessibility, they have the potential to become the most prominent objects. ${ }^{6}$ One such favourable condition may be the restoration of heritage sites to their former glory and making them available to the public by giving them a cultural function. Perhaps, then, the analysed PPCs could be an impulse triggering the development of many communities and areas that are threatened by amarginalisation. ${ }^{7}$ A particular problem with exploiting the potential of historical PPCs can be observed in post-socialist countries such as Poland.

The aim of the study was to assess the concept of culture-led regeneration as applied to palace and park complexes situated in rural areas at risk of marginalisation in a post-socialist country, Poland, using the case of Kujawsko-Pomorskie Voivodeship. ${ }^{8}$

\footnotetext{
${ }^{2}$ APP, Benjamin, BAUER, Judith, BOMBANA, Tiziano, BORGES, Marisa, OBERSCHMIDT, Anja. The Palaces and Parks of Potsdam and Berlin, accessed 15 January 2020, http://citeseerx.ist.psu.edu/viewdoc/download?doi=10.1.1.199.1622\&rep=rep1\&type=pdf; SU, Ming Ming, WALL, Geoffrey. Exploring the shared use of world heritage sites: Residents and domestic tourists' use and perceptions of the summer palace in Beijing. In: International Journal of Tourism Research, Vol. 17, No. 6, 2015, pp. 591-601.

${ }^{3}$ DRAGAN, Weronika, DYMITROW, Mirek, KRZYSZTOFIK, Robert. Between History, Politics and Economy: The Problematic Heritage of Former Border Railway Stations in Poland. In: Mitteilungen der Österreichischen Geographischen Gesellschaft, Vol. 161, 2019, pp. 229-250.

${ }^{4}$ TIŠLIAR, Pavol, KAČÍREK, Luboš, JANTO, Juraj. History and memory of hospital sites. On the example of the "old" hospital in Topol’čany. In: Muzeológia a kultúrne dedičstvo, Vol. 8, No. 1, 2020, pp. 31-45.

${ }^{5} \mathrm{NASH}$, Robert, MARTIN, Andrew. Tourism in peripheral areas - the challenges for northeast Scotland. In: International Journal of Tourism Research, Vol. 5, No. 3, 2003, pp. 161-181.

${ }^{6} \mathrm{NASH}, \mathrm{MARTIN}$, Tourism in peripheral areas...

${ }^{7}$ BAŻANT, Dominik, BUDNICKA-KOSIOR, Joanna, GRZEGORZEWICZ, Ewelina, KACZMARSKI, Zdzisław, OLENDEREK, Tomasz. Parki wiejskie jako zasoby lokalne-badania stanu i zmian. In: Studia $i$ Materiaty Centrum Edukacï Pryyrodniczo-Leśnej, Vol. 49B, No. 5, 2016, pp. 54-60.

${ }^{8}$ voivodeship_-administrative region of the 1 st order in Poland
} 


\section{Palace and park complexes in Poland}

The untapped potential of Poland's PPCs and their continuing dilapidation, resulting in their disappearance from rural landscapes, is the outcome of many negative factors that were triggered by the events of the second half of the twentieth century.

The first stage in the destruction of historical PPCs was the ambiguous ownership status of many of them after the end of World War II. Abandoned but relatively complete despite the German occupation, PPCs were being taken over by the Russian army and "looted and destroyed by [...] troops stationed nearby or on their grounds, as well as by civilians".?

The next stage came with the nationalisation of private property in Poland after 1945, ${ }^{10}$ which resulted in the devastation and destruction of many PPCs in the country. ${ }^{11}$ The change in their function was related to the disruption of the role they had traditionally played in rural areas. Their decline was programmed for ideological reasons and was accompanied by propaganda against the land-owning class that they symbolised. ${ }^{12}$ As a result of the nationalisation of rural estates in the so-called Recovered Territories (the western and north-eastern parts of Poland that before 1939 had belonged to the German Reich), the manifesto of the Polish Committee of National Liberation (PKWN; an interim government of the Republic of Poland active between 21 July and 31 December 1944), and the agrarian reform decree of 1944, PPCs in Poland became the property of the State Treasury. In consequence, until 1989, most of them were used for public purposes by institutions, and became the seats of town and communal authorities, State Farms, farmers' cooperatives, schools, kindergartens, health centres, nursing homes, community centres, post offices, experimental agricultural facilities, and community cooperatives. The historical and valuable buildings and parks were turned into spaces where services were provided. Some rooms were used as the living quarters by the institutions' staff while others were converted into storage areas or warehouses, and parks were turned into vegetable gardens and orchards. ${ }^{13}$ PPCs were frequently repaired and rebuilt, but most of the works were not supervised by heritage conservation officers. Especially neglected were the parks surrounding the palaces. It was only in 1975 that the Minister of Culture and Arts initiated an all-Poland inventory of gardens and parks. The programme was supervised by the Heritage Landscape Centre until 2002 when it was incorporated into the National Heritage Centre for Heritage Studies and Documentation (now the National Heritage Board of Poland-NID).

\footnotetext{
${ }^{9}$ RZESZOTARSKA-PAŁKA, Magdalena. Threats of palaces and manors-garden ensembles on the area of West Pomerania connected with structural transformations of rural areas in 20th and 21 st century. In: Technical Transactions. Architecture Issue, Vol. 5-A, No. 5, 2016, p. 226.

${ }^{10}$ STRASZAK-CHANDOHA, Sylwia. Polityczno-ekonomiczne uwarunkowania sytuacji rolnictwa w PRL. In: CHUMIŃSKI, Jędrzej, ed. Modernizacja czy pozorna modernizacja. Spoteczno-ekonomiczny bilans PRL 1944-1959. Wrocław: Gajt, 2010, pp. 362-398; MERTA-STASZCZAK, Adriana. Rola gmin w zagospodarowaniu zabytkowych nieruchomości na Dolnym Śląsku. In: Ochrona Zabytków, Vol. 2, pp. 191-217.

${ }^{11}$ DUTKIEWICZ, Józef Edward. Dwadzieścia lat ochrony zabytków w Polsce Ludowej. In: Ochrona Zabytków, Vol. 17, No. 2, 1964, pp. 6-14; PAWLIKOWSKA-PIECHOTKA, Anna. Nieruchomość zabytkowa jako lokata kapitału: motywacje inwestorów. In: Ochrona Zabytków, Vol. 54, No. 2, 2001, pp. 133-142; GUBAŃSKA, Renata. Zagospodarowanie turystyczne założeń pałacowo-folwarcznych szansą aktywizacji dolnośląskiej wsi. Nauka Pràyroda Technologie, Vol. 2, No. 4, 2008, Article No. 40; RZESZOTARSKA-PAŁKA, Threats of palaces...

${ }^{12}$ PAWLIKOWSKA-PIECHOTKA, Nieruchomość zabytkowa...

${ }^{13}$ PAWLIKOWSKA-PIECHOTKA, Nieruchomość zabytkowa...
} 
S. Środa-Murawska et al.: Culture-led regeneration as a vital instrument for preserving the cultural heritage...

The last stage that put an end to the existence of some PPCs involved privatisation and restitution of properties to their legitimate owners after $1989 .{ }^{14}$ Privatisation of properties was based on the parliamentary act of 19 October 1991 "On the management of agricultural land held by the State Treasury and the establishment of the Treasury's Agency for Agricultural Property (AWRSP)". According to the plan, by the end of 1993 the Agency was to take over all property held by the disbanded State Farms, including PPCs. Thus, it assumed responsibility for historical objects that became the State's possession again. Its primary task, however, was the sale or lease of buildings and land. The contracts with new owners or users obligated them to take proper care of and maintain buildings, but as many of the estates were in a poor state of repair they were not attractive to potential buyers. Consequently, most transactions involved farming land. As the economic situation in the country improved, more investors took interest in PPCs and in protecting them from falling into ruin and disintegration.

The register of historic monuments covers 7,449 historical green sites $(10.5 \%$ of all immovable historic properties) including parks, gardens, alleys, and the elements of the natural landscape. Most historical parks and gardens can be found in the Wielkopolskie, Mazowieckie, Dolnośląskie, and Zachodniopomorskie voivodeships. ${ }^{15}$

The NID survey has shown that the majority of historical parks and gardens show symptoms of disrepair, which are minor in the case of $40.5 \%$ of objects, moderate in $27.0 \%$, and severe in $10.8 \%$. Only $21.6 \%$ of historical green parks and gardens are in a good state of repair. As regards the correspondence between their present-day and historical character, merely $12.2 \%$ have preserved their historical substance, $46.6 \%$ are largely unchanged, $31.8 \%$ have changed to a limited extent, and $9.5 \%$ do not or barely resemble what they were. Only $6.1 \%$ have retained all of their historical substance.

\section{Culture-led regeneration outside the cities}

Culture has been viewed in recent years as a factor driving the development of European cities, ${ }^{16}$ especially in the context of postmodernist changes influencing urban spatial structures or their functions. According to Landry, ${ }^{17}$ culture can strengthen social cohesion in cities and stimulate their residents' self-confidence and resourcefulness, as well as improve their mental and physical condition, encourage democratic behaviours, inspire them to seek new education paths, and shape their careers. Despite the stereotypical perception of culture as a form of pastime, its associations with economy are being increasingly appreciated and seen. ${ }^{18}$ Throsby's work ${ }^{19}$ provides a comprehensive explanation of how the two worlds are related to each other. It observes that the economic discourse and economic systems are set in a cultural context, and that cultural processes only exist in the economic environment.

\footnotetext{
${ }^{14}$ GANCARZ-ŻEBRACKA, Jadwiga. Współczesne adaptacje historycznych założeń pałacowo-parkowych. Wybrane przykłady. In: Teka Komisji Arcbitektury, Urbanistyki i Studión Krajobrazonych, Vol. 9, No. 2, 2013, pp. 32-42; GUBAŃSKA, Renata. Zatożenia resydencjonalno-folwarcz̨ne na Dolnym Ślasku. Możliwości adaptacji do nowej funkcji. Wrocław: Wydawnictwo Uniwersytetu Przyrodniczego, 2014; MERTA-STASZCZAK, Rola gmin...

${ }^{15}$ Narodowy Instytut Dziedzictwa (NID). Raport o stanie zachowania zabytków nieruchomych w Polsce. Zabytki wpisane do rejestru zabytkón (ksiegi rejestru A i C). Warszawa: Narodowy Instytut Dziedzictwa, 2017.

${ }^{16}$ LANDRY, Charles. The Creative City: A Toolkit for Urban Innovators. London: Routledge, 2012.

${ }^{17}$ LANDRY, The Creative City...

${ }^{18}$ BENDIXEN, Peter. Einfübrung in die Kultur- und Kunstökonomie. Wiesbaden: Springer, 2001; THROSBY, David. Economics and Culture. Cambridge: Cambridge University Press, 2001; FLORIDA, Richard. The rise of the creative class and how it's transforming work, leisure, community and everyday life. New York: Basic Books, 2004.

${ }^{19}$ THROSBY, Economics and Culture.
} 
In the literature, culture-based development tends to be considered using the examples of specific cities, neighbourhoods, or streets, as well as being linked to activities closely related to cultural institutions. However, the cultural sector should also be considered in terms of the development of local systems where it frequently plays a central role.

A fundamental change in the perception of the status of the cultural sector should be attributed to societal changes after 1968 and the advent of the post-industrial era. With mounting problems caused by the liquidation of factories and rising unemployment, etc., European cities "rediscovered" culture in the 1980s, this time as a potential driver of economic development. ${ }^{20}$ The next years witnessed the increasing use of culture-led regeneration as a means of revitalising entire city districts.

Using culture as an instrument of revitalisation generally means a process in which it is used to revitalise dilapidated areas. A classification of culture-led regeneration models has been presented by Evans and Shaw, ${ }^{21}$ who proposed:

- culture-led regeneration - encompassing the designing, construction, and/or revitalisation of public or commercial buildings; the regeneration of public spaces; the implementation of programmes aimed at changing the image of the place;

- cultural regeneration - consisting of integrated activities in the social, economic, and environmental spheres, and cultural planning;

- culture and regeneration - including cultural activities outside the cities' flagship projects; activities of independent organisations establishing cultural events in support of positive changes in cities.

Culture-led regeneration is mainly studied with respect to cities, mostly the largest ones. ${ }^{22}$ Smaller cities attract less attention, ${ }^{23}$ and rural areas scarcely any. Exceptions are the works by authors such as Lewis et al., ${ }^{24}$ Roberts and Hall, ${ }^{25}$ McKay, ${ }^{26}$ von Rohrscheidt, ${ }^{27}$ or Smith, ${ }^{28}$ who explore the rural areas' potential for culture-based development. And yet, rural areas in post-socialist countries, as well as in other parts of Europe and the world, struggle with many problems, including population shrinking and ageing, emigration of young people, limited

\footnotetext{
${ }^{20}$ ŚRODA-MURAWSKA, Stefania. Rozwój oparty na sektorze kultury-doświadczenia średnich miast w Polsce. Toruń: Wydawnictwo Naukowe Uniwersytetu Mikołaja Kopernika w Toruniu, 2019.

${ }^{21}$ EVANS, Graeme, SHAW, Phyllida. The Contribution of Culture to Regeneration in the UK: A Review of Evidence. A report to the Department for Culture, Media and Sport. London: London Metropolitan University, 2004.

22 ŚRODA-MURAWSKA, Rozwój oparty na...

${ }^{23}$ ŚRODA-MURAWSKA, Stefania, BIEGAŃSKA, Jadwiga, DAßBROWSKI, Leszek. Perception of the role of culture in the development of small cities by local governments in the context of strategic documents-a case study of Poland. In: Bulletin of Geography. Socio-economic Series, Vol. 38, 2017, pp. 119-129; ŚRODA-MURAWSKA, Stefania. Railway feat. Culture-Rumia library effect as an example of the influence of culture-led regeneration in a medium-sized city in Poland. In: Cities, Vol. 106, 2020.

${ }^{24}$ LEWIS, David, BEBBINGTON, Anthony J., BATTERBURY, Simon P.J., SHAH, Alpa, OLSON, Elizabeth, SIDDIQI, M. Shameem, DUVALL, Sandra. Practice, power and meaning: frameworks for studying organizational culture in multi-agency rural development projects. In: Journal of International Development, Vol. 15, No. 5, 2003, pp. 541-557.

${ }^{25}$ ROBERTS, Lesley, HALL, Derek. Consuming the countryside: Marketing for 'rural tourism'. In: Journal of Vacation Marketing, Vol. 10, No. 3, 2004, pp. 253-263.

${ }^{26}$ MCKAY, George. Circular breathing: The cultural politics of jazz in Britain. Durham: Duke University Press, 2005.

${ }^{27}$ VON ROHRSCHEIDT, Armin Mikos. Turystyka kulturowa: fenomen, potencjat, perspektywy. Gniezno: GWSHM Milenium, 2008.

${ }^{28}$ SMITH, Larry W., Jr. Urban indigenous culture in Los Angeles County. California: California State University, Long Beach, 2011.
} 
economic growth, etc. ${ }^{29}$ Culture, including folk culture, is a natural and original embodiment of regions' cultural heritage that is frequently used as a promotional vehicle, in some cases being the economic basis of their economic development. ${ }^{30}$

For many small locations, folk culture present in rural areas has served as a basis for changes and the trigger of local development. Modelled by local communities, non-governmental organisations and local authorities, it turns into a rich cultural offer that stimulates development, ${ }^{31}$ understood not only as economic progress but also as the consolidation of the identity and heritage of the region. ${ }^{32}$ A perfect example of the exploitation of the cultural heritage of rural areas is cultural tourism, which still tends to be associated with visiting monuments and museums. ${ }^{33}$ Cultural tourism is frequently indicated as an instrument of local and regional development, especially in the context of multifunctional rural development and support for economically less-developed areas. Special efforts in this field are made by EU member states. ${ }^{34}$

Therefore, excluding culture-led regeneration from investment projects involving PPCs seems irrational, especially given that successful PPC revitalisation projects not only help preserve the existing heritage, but also, in an increasing number of cases, boost local development. ${ }^{35}$

Having been established as principal private residences, the majority of PPCs have significant historical value. They were originally held by private owners, but in time they were transformed into spaces open to the public and modified inside and outside to improve their functionality. Unfortunately, with the change of function, many of them fell in disrepair while losing their natural and cultural values. The process was especially noticeable in the former socialist countries.

Maintaining the objects in a proper state of repair or bringing them back to it is practically a must, given their roles as the embodiment of cultural heritage and as assets in visually attractive areas. ${ }^{36}$ The revalorisation or revitalisation of PPCs aimed at mitigating the impacts of functional and environmental changes, as well at ensuring that they have the desired functionality, is faced with various challenges:

- compositional - the assessment of the match between the original layout of the park

${ }^{29}$ DUXBURY, Nancy, CAMPBELL, Heather. Developing and Revitalizing Rural Communities through Arts and Culture. A Literature Review. In: Small Cities Imprint, Vol. 3, No. 1, 2011, pp. 111-122.

${ }^{30}$ ROBERTS, HALL, Consuming the countryside...; VON ROHRSCHEIDT, Turystyka kulturowa...; SMITH, Urban indigenous culture...

${ }^{31}$ PANELLI, Ruth. Young rural lives: strategies beyond diversity. In: Journal of Rural Studies, Vol. 18, No. 2, 2002, pp. 113-122; SLAMA, Kay. Rural Culture is a Diversity Issue. In: Minnesota Psychologist, Vol. 53, No. 1, 2004, pp. 9-13; SMITH, Urban indigenous culture...; SMALLEY, K. Bryant, WARREN, Jacob C. Rurality as a diversity issue. In: SMALLEY, K. Bryant, WARREN, Jacob C., RAINER, Jackson P., eds. Rural mental health: Issues, policies, and best practices. New York: Springer Publishing Company, 2012, pp. 37-47.

${ }^{32}$ LEWIS et al., Practice, power...; BRENNAN, Mark A., FLINT, Courtney G., LULOFF, A.E. Bringing together local culture and rural development: Findings from Ireland, Pennsylvania and Alaska. In: Sociologia Ruralis, Vol. 49, No. 1, 2009, pp. 97-112.

${ }^{33}$ LANE, Bernard. What is rural tourism? In: Journal of Sustainable Tourism, Vol. 2, Nos. 1-2, 1994, pp. 7-21; SHARPLEY, Richard, ROBERTS, Lesley. Rural tourism - 10 years on. In: International Journal of Tourism Research, Vol. 6, No. 3, 2004, pp. 119-124; SLAMA, Rural Culture...

${ }^{34}$ NURYANTI, Wiendu. Heritage and postmodern tourism. In: Annals of Tourism Research, Vol. 23, No. 2, 1996 , pp. 249-260; RICHARDS, Greg. Cultural Tourism in Europe. Oxon: CAB International, 1996.

${ }^{35}$ MURZYN-KUPISZ, Monika. Wpływ przedsięwzięć związanych z odnową obiektów i miejsc zabytkowych na gospodarkę lokalną i regionalną. In: Ochrona Zabytków, Vols. 1-4, 2010, pp. 139-156.

${ }^{36}$ SOLDANI, Alberto, JANKOWSKI, Dariusz. Zabytki. Ochrona i opieka. Praktyczny komentarz do nowej ustawy. Tekst Ustawy z dnia 23 lipca 2003 r. Zielona Góra: ZCO, 2004. 
and the expectations of its contemporary users;

- environmental - such as the influence of the environmental aspects of the park, especially its vegetation, on the projected reconstruction;

- programmatic - the assessment of what proportion of the historic value can be built into the new functionality;

- economic - the analysis of the final cost of the project considering the restoration or revitalisation costs and maintenance costs. ${ }^{37}$

An example of revitalisation works undertaken for the above reasons is the activities implemented under the HICAPS project in historical parks in four European countries: Slovenia, Italy, Croatia, and Poland. The countries participating in the project under the socalled international partnership seek to develop the best path for developing PPCs, mainly by their renewal and revitalisation. Each area covered by the project has been assigned specific goals and improvement targets, such as education, increased accessibility to people with disabilities or families with children, etc. ${ }^{38}$

\section{Methodology}

The analysis of the applicability of the culture-led regeneration concept to PPCs in areas at risk of marginalisation (such as rural areas in post-socialist countries) will be performed on PPCs located in three Polish villages: Lubostroń, Szafarnia, and Wieniec (see Figure 1). These specific PPCs were selected because they are nationally representative examples of cultureled regeneration used to ensure their sustainability. All three objects are administered by local authorities and are similar in that they perform purely cultural functions far from larger cities.

The first step in the research was the analysis of PPCs across the Kujawsko-Pomorskie Voivodeship. The basic source of information was the register of immovable monuments kept by the Voivodeship Monuments Conservation Office in Torun and the data obtained from the NID (a field branch in Toruń). Information on each park's area, preserved historical boundaries, layouts, water systems, and buildings was compiled from the documentation available at the Voivodeship Monuments Conservation Office in Toruń and its branches in Bydgoszcz and Włocławek. In total, documents relating to 324 historical parks were collected (for the other 45 parks no documentation was available). Information on whether any monuments of nature were present in the parks was obtained from the Central Register of the Forms of Nature Protection. The main source of other information (ownership, availability to visitors, and usage type) were tabulated data obtained from the NID.

Because the preliminary scope of research was very wide, it was narrowed down using the results of sociological (qualitative) and quantitative analyses. They were used to diagnose the needs of the local community in the context of the park-use concept. Another purpose of the sociological analysis was to assess the local community's acceptance of the ongoing restoration or revitalisation process according to the culture-led regeneration concept.

A survey and in-depth interviews were conducted in the village of Wieniec between 6 and 7 August 2018, with 116 respondents aged from 16 to 84 years who differed in sociodemographic characteristics (marital status, gender, education, economic status). It was also

\footnotetext{
${ }^{37}$ FORTUNA-ANTOSZKIEWICZ, Beata, GAWŁOWSKA, Agnieszka, ŁUKASZKIEWICZ, Jan, ROSŁON -SZERYŃSKA, Edyta. Problemy rewaloryzacji i ochrony parków historycznych w centrum miasta na przykładzie Ogrodu Krasińskich w Warszawie. In: Technical Transactions. Architecture Issue, Vol. 109, No. 6-A, 2012, pp. $145-166$. ${ }^{38}$ Interreg_Central Europe. Work package T3_Revitalization concepts and test of outputs on pilot sites, accessed 15 January 2020, https://www.interreg-central.eu/Content.Node/WPT3.htm
} 
ensured that the respondents had had different periods of residence in Wieniec, as this could have significantly influenced their opinions.

The aspects of PPC management in the context of culture-led regeneration were identified based on:

- an interview with Ms. Anna Wołek, director of the Kujawsko-Pomorski Impresario Music Theatre in Toruń;

- the findings of a study visit;

- the analysis of documents such as the Feasibility Study of an Investment Project, "The Establishment of the Kujawskie Music Centre in the Wieniec Palace-The Repair, Alteration and Modernisation of the Palace and Park Complex in Wieniec near Włocławek including its external infrastructure and the upgrading of the Park area" (Torun, April, 2017).

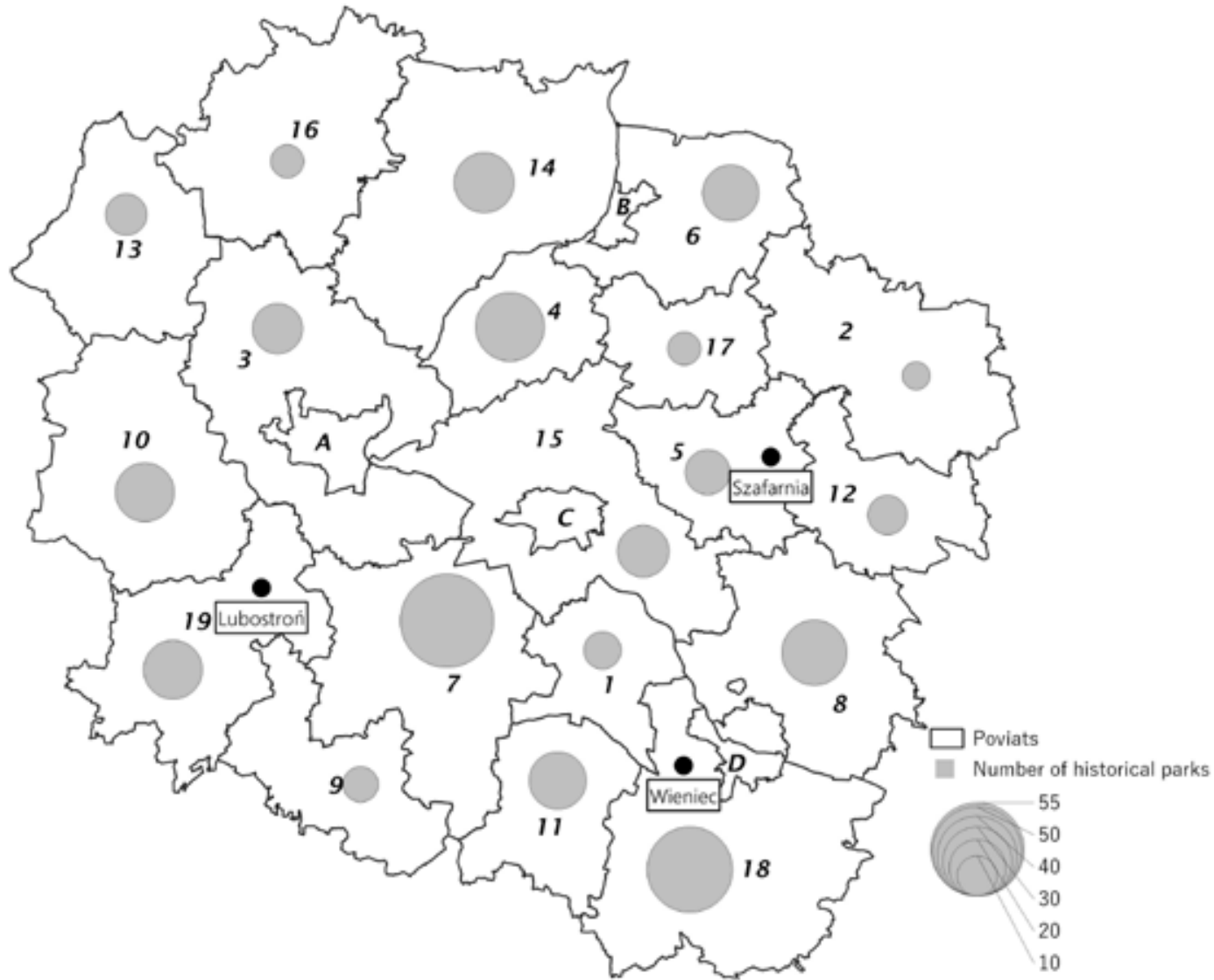

Fig. 1: Number of PPCs in Kujawsko-Pomorskie Voivodeship in 2018 by poviats

Source: developed by the authors based on the Voivodeship Monuments Conservation Office in Torun and NID data

Key: Poviats of: 1 - Aleksandrów, 2 - Brodnica, 3 - Bydgoszcz, 4 - Chełmno, 5 - Golub-Dobrzyń, 6

- Grudziądz, 7 - Inowrocław, 8 - Lipno, 9 - Mogilno, 10 - Nakło, 11 - Radziejów, 12 - Rypin, 13

- Sępólno Krajeńskie, 14 - Świecie, 15 - Toruń, 16 - Tuchola, 17 - Wąbrzeźno, 18 - Włocławek, $19-\grave{Z} \operatorname{nin}$

City with poviat rights: A - Bydgoszcz, B - Grudziądz, C - Toruń, D - Włocławek 


\section{Results}

The Kujawsko-Pomorskie Voivodeship has a total of 369 historical parks, covering an area of 1803.38 ha. Because of their poor state of repair, three of them require immediate intervention: those in Żołędowo (poviat ${ }^{39}$ of Bydgoszcz, commune ${ }^{40}$ of Osielsko), Broniewo (poviat of Radziejów, commune of Radziejów), and Dąbrówka (poviat of Włocławek, commune of Kowal). Another three exist only in legal terms, in that all that is left of them is entries in the register of monuments and the estate documentation: those in Kamienica (poviat of Lipno, commune of Dobrzyń nad Wisła), Lipienica-Żuławy (poviat of Świecie, commune of Świekatowo), and Kaniewo (poviat of Włocławek, commune of Boniewo). As the result of a query, the documentation on 324 historical parks was collected (for the remaining 45 parks no documentation is available).

The largest numbers of historical parks in the Kujawsko-Pomorskie Voivodeship occur in the poviats of Inowrocław (55) and Włocławek (46). Twelve poviats have between 10 and 30 parks, and four poviats have fewer than 10 parks: Aleksandrów Kujawski (9), Mogilno (8), Tuchola (7), and Wąrzeźno (7). The poviat with the smallest number of historical parks is Brodnica (5) (see Figure 1).

The uneven distribution of PPCs across the voivodeship has been caused by natural, economic, historic, cultural, and political factors. The largest number of parks can be found in poviats that lie in historically important regions, a case in point being the PPCs in the poviats of Chełmno, Inowrocław, and Włocławek in the Kujawsko-Pomorskie Voivodeship. An important factor determining the present-day locations of PPCs in the voivodeship is the difference in levels of economic development, which used to be highest in the former Prussian partition. ${ }^{41}$ Its area was characterised by a denser network of settlements and a more advanced farming culture. New, grand residences were also built along vital trade routes, following the trend observed in Western Europe. In contrast, small numbers of PPCs in some poviats, e.g. in the north-eastern part of the voivodeship, should be attributed to the less developed economy in the former Russian partition, sparse settlements, and fewer roads.

The majority $(68 \%)$ of historical parks in the voivodeship under consideration have remained in their old boundaries, and over half of them have retained their original layout. Almost a quarter of parks have lost their original water systems, but $41 \%$ have preserved them to date. An interesting finding was that $23 \%$ of the parks never had a water system. A large number of parks with original borders and layouts, including water systems, testify to the high quality and value of this type of object in the Kujawsko-Pomorskie Voivodeship. Almost all of them $(96 \%)$ still have manors or palaces with adjacent utility buildings (stables, barns, etc.). In the other parks, neither the buildings nor their ruins have survived.

Most historical parks in the voivodeship (64\%) are public property and so they are open to visitors. Parks on public grounds are more readily accessible to people who want to enjoy their greenery. In total, over $80 \%$ of heritage parks invite visitors, including some parks held by private owners. The use of parks is basically determined by the type of activity conducted in the PPC. Of the heritage parks under consideration, only $30 \%$ have a defined use; most of the others are falling into neglect but are open to visitors, as opposed to those in private hands.

\footnotetext{
${ }^{39}$ poviat-administrative region of the 2 nd order in Poland

${ }^{40}$ commune-administrative region of the 3 rd order in Poland

${ }^{41}$ Between 1772 and 1918 the Polish territory was divided between the partitioners. From 1815 one of the borders ran through the current Kujawsko-Pomorskie Voivodeship. The north-western area of the voivodeship belonged to Prussia and the south-eastern part to Russia.
} 
In 98 parks, out of 369, service activities were carried out in 2018. In the group of 98 PPCs, the predominant types of use included restaurant and hospitality services $(20.4 \%)$, educational services (18.4\%), agricultural services (17.3\%), and social services $(15.3 \%)$. Less frequent were cultural services $(14.3 \%)$, housing services $(8.2 \%)$, business services $(5.1 \%)$, and administrative services $(1.0 \%)$ (see Figure 2 ). Restaurant and hospitality services are typically provided in privately owned PPCs, whereas most PPCs in public possession are used to deliver educational, social and cultural services.

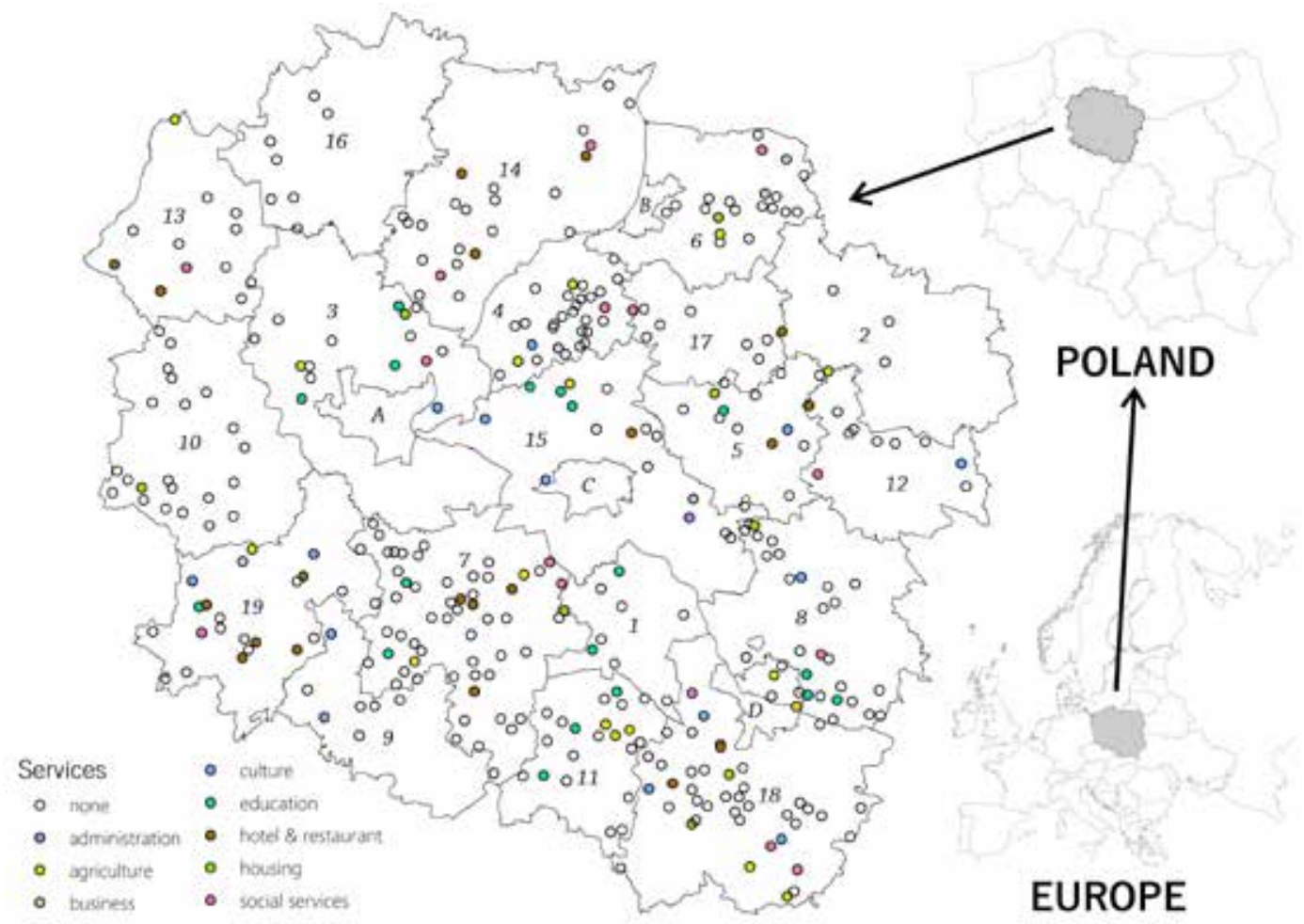

Fig. 2: Location of the PPCs and their function in Kujansko-Pomorskie Voivodeship in 2018 by poviats

Key: Poviats of: 1 - Aleksandrów, 2 - Brodnica, 3 - Bydgoszcz, 4 - Chełmno, 5 - Golub-Dobrzyń, 6 Grudziądz, 7 - Inowrocław, 8 - Lipno, 9 - Mogilno, 10 - Nakło, 11 - Radziejów, 12 - Rypin, 13 - Sępólno Krajeńskie, 14 - Świecie, 15 - Toruń, 16 - Tuchola, 17 - Wąbrzeźno, 18 - Włocławek, $19-\ddot{Z} \operatorname{nin}$

City with poviat rights: A - Bydgoszcz, B - Grudziądz, C - Toruń, D - Włocławek

Source: developed by the authors based on the web data

Among the 14 PPCs that now function as cultural facilities, 2 have private owners, 4 are held by religious foundations, and the other 8 are administered by commune or voivodeship governments. Four PPCs are museums, 2 house libraries, and the others, including the PPC in Wieniec that is in the process of renovation, are used as cultural centres. Because of their importance for local development, 3 PPCs, in Lubostroń, Szafarnia, and Wieniec, will be subjected to a more thorough analysis. 


\section{The palace and park complex in Lubostron}

The village of Lubostron lies in the poviat of Żnin, in the commune of Labiszyn (see Figure 1). The entire historic park complex in the village covers 42.34 hectares. It can be reached via an alley bordered by elm and hornbeam trees, with two massive brick obelisks by the entrance gates. Behind the centrally situated palace, there is a view over the gently declining slopes towards the Notec river. ${ }^{42}$ The layout of the historic park has not changed since it was designed. Its good condition today is owed to the fact that it has only been subjected to the necessary renovation and restoration works. Between the palace and the river, there is a small pond with an islet in the centre. In the past, it was connected with the river which supplied it with water for drinking and other uses. It is the only element related to the water system so it can be said that the water system in the park has been fully preserved. ${ }^{43}$

The PPC in Lubostron consists of an outbuilding called the "Old Palace", three-storey coach houses, stables, the neo-gothic utility buildings, the gardener's house, a hunting cottage, and a neoclassical palace being the dominant element of the estate. ${ }^{44}$ The park around the neoclassical palace was designed by the then respected architect, gardener, and urban planner Oscar Tiechert.

The palace in Lubostron is a unique example of a centrally located structure designed on a square plan. Its features strongly resemble Villa Rotonda and Villa Trissimo in Italy. ${ }^{45}$ The palace was erected at the heart of the park between 1795 and 1800 and served as a residence and scientific facility for the Polish elite. The PPC and the landscape around it together form an extensive spatial composition, which makes the neo-classicist palace one of the most beautiful residences in Poland. Both the park and the palace are public property in possession of the Treasury of the Republic of Poland.

The PPC in Lubostron is the seat of activities aimed at promoting national heritage and various forms of culture and arts. The palace houses an institution, the purpose of which is to protect and maintain the entire historic complex, by:

- upholding its historical, architectural, and natural values;

- developing and implementing various cultural and artistic projects, especially concerts, exhibitions, and literary and theatre events;

- delivering workshops and improving courses on different arts;

- creating a tourist offer promoting the historic and architectural values of the PPC in Lubostroń complex and artistic activities conducted therein;

- collecting and exhibiting items of culture.

\section{The palace and park complex in Szafarnia}

The Szafarnia PPC is situated in a village of the same name, located in the commune of Radomin, poviat of Golub-Dobrzyń (see Figure 1). With a total area of 3.6 ha, this PPC belongs to a large group of medium-sized estates with an acreage of between 2 and 5 ha.

\footnotetext{
${ }^{42}$ CHMIELNIK, Hanna. Park zabytkowy w Lubostroniu reaydencji Skórzewskich na Pałukach. Lubostroń, Bydgoszcz: Eko-Park, 2013.

${ }^{43}$ CHMIELNIK, Park zabytkowy...

${ }^{44}$ KAJA, Renata. Przewodnik po zespołach palacowych i dworskich: walory prayrodniczo-architektoniczne. Bydgoszcz: Wydawniczo-Promocyjna Agencja Duo-Press, 2002.

${ }^{45}$ JANKOWSKI, Aleksander. Pałac w Lubostroniu Fryderyka Skórzewskiego: pomnik rodowej dumy $i$ zamitowania sz̨tuk plastycznych. Bydgoszcz: Wydawnictwo Uniwersytetu Kazimierza Wielkiego, 2014.
} 
S. Środa-Murawska et al.: Culture-led regeneration as a vital instrument for preserving the cultural heritage...

The park in Szafarnia was formally granted the status of a historic monument on 30 January 1960. It now houses the Chopin Centre, a cultural institution managed by the government of Kujawsko-Pomorskie Voivodeship. The Centre was created to commemorate the visits of young Frederic Chopin in Szafarnia in 1824 and 1825. However, the Centre's activities are not limited to being a place where memories and old souvenirs are collected and stored, as it also provides space for concerts and exhibitions. Cyclical concerts that draw a regular audience as well as an increasing number of new music lovers are held at least several times a month. One of the Centre's priorities is cultural and musical education, which is offered to the public through broadcasts for children and adults, mastery workshops or classes, piano and recitation contests, quizzes about Frederic Chopin, photo and painting exhibitions, and theatre performances. ${ }^{46}$

The park has retained its original layout including the arrangement of the buildings and their authenticity. The system of local roads leading to the estate and the original water system have not changed either. A valuable asset of the park established in the first half of the twentieth century is the diversity of old trees, among which hornbeams and maples predominate. The park is considered to represent a landscape (naturalistic) park, a variation of the English park. Such parks were highly popular in Poland in the nineteenth and twentieth centuries. The palace and park complex in Szafarnia comprises:

- a neoclassical residence built in the second half of the nineteenth century, renovated in 1927 and 1960, and rebuilt after a fire in 1979;

- a former outbuilding;

- utility buildings with a section of the former grange;

- a sports court;

- a parking area.

The front of the palace, which is situated in the eastern part of the park, faces south-east. The building was erected of brick on a rectangular plan, with basements under some sections. The park, which is not fenced, is bordered on each side by farmers' houses and farmland.

\section{The palace and park complex in Wieniec}

The palace and park complex in Wieniec is an interesting case of a project in process. On 10 October 2019, it became the construction site for the Music Theatre.

The PPC in Wieniec is situated in the poviat of Włocławek, in the commune of Brześć Kujawski (see Figure 1). The estate has retained its historical borders and layout. The latter can still be seen in the basic elements of the old plan. Most importantly, the palace has generally retained the character of the residence because of Leopold Kronenberg, a reputable Warsawbased banker, industrialist, economic activist, and politician. ${ }^{47} \mathrm{He}$ purchased the Wieniec estate at an auction on 31 August 1869 and then hired the architect Artur Goebel who design the PPC in the second half of the nineteenth century. ${ }^{48}$

The new, stately palace in Wieniec was then modernised by Leopold Kronenberg's two sons. In 1902, Leopold Julian Kronenberg had renovation work carried out on the park in Wieniec, but no archival sources have been preserved to confirm this. After his death, the estate passed on to his son Leopold Jan, in the possession of whom it remained until World War II when it

\footnotetext{
${ }^{46}$ S zafarnia. History, accessed January $15^{\text {th }}, 2020$, http://www.szafarnia.art.pl/en/historia/

47 ŻOR, Andrzej. Kronenberg. Drieje fortuny. Warszawa: Wydawnictwo Naukowe PWN, 2011.

${ }^{48}$ CELIŃSKA, Elżbieta, GRUSZCZYŃSKA, Marianna. Wieniec_zespół pałacowy. In: KUNIKOWSKI, S., ed. Materialy do dziejów reasdencii w Polsce, Kujawy W schodnie, Tom I, cæessic 2. Włocławek: Włocławskie Towarzystwo Naukowe, 2001, pp. 239-284.
} 
was appropriated by the Germans. After the war, the estate was nationalised and taken over by the Treasury pursuant to the agricultural reform act of 24 August 1945. After 1949 the estate served as a tuberculosis sanatorium that in 1960 was renamed the Department of Tuberculosis and Lung Diseases of the Voivodeship Hospital in Włocławek and performed this function until 2006. At present, the palace and the park are owned by the Marshal's Office of the Kujawsko-Pomorskie Voivodeship. They are managed on its behalf by the Kujawsko-Pomorski Impresario Theatre.

The PPC in Wieniec is one of the most magnificent palace and park complexes that have been preserved in the Cuiavian ethnographical region (the southern part of KujawskoPomorskie Voivodeship). The estate currently comprises:

- the new palace;

- the old palace;

- gatehouse / guardhouse at the entrance gate;

- the old engine house.

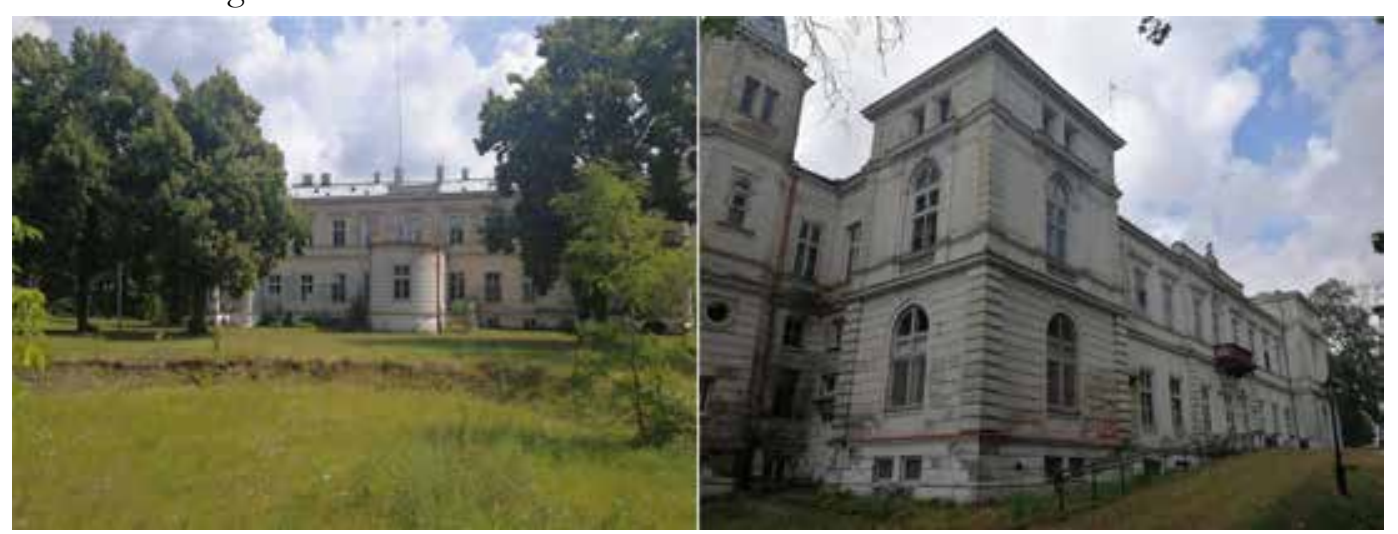

Pict. 1: The Kronenbergs' Palace in Wieniec (on the left is a part of the eastern elevation, on the right, part of the western elevation)

Source: authors

The PPC in Wieniec will run a number of cultural projects. Some of them will be carried out in cooperation with the Museum of the Cuiavian and Dobrzyn Land in Włocławek.

The main projects involve the delivery of concerts and music workshops aimed at promoting young, talented local artists, and students and graduates of music schools in the region and of the Feliks Nowosielski Music Academy in Bydgoszcz. They will also provide an opportunity for young Polish and foreign artists to present their skills and to gain their first experiences of performing in public during concerts of chamber music and other events (theatre plays, monodramas, etc.). It is intended that around 15 music and theatre events and conferences will be organised every year.

The PPC will also run a culture-oriented educational programme involving the delivery of workshops for professional actors and musicians, as well as amateur artists of all ages. The range of courses will include singing, dancing, choreography, and drama classes at different levels - from acting lessons to teaching the creation of mini performances, small theatre forms, and the ways of merging different forms of expression such as pantomime and dance. 


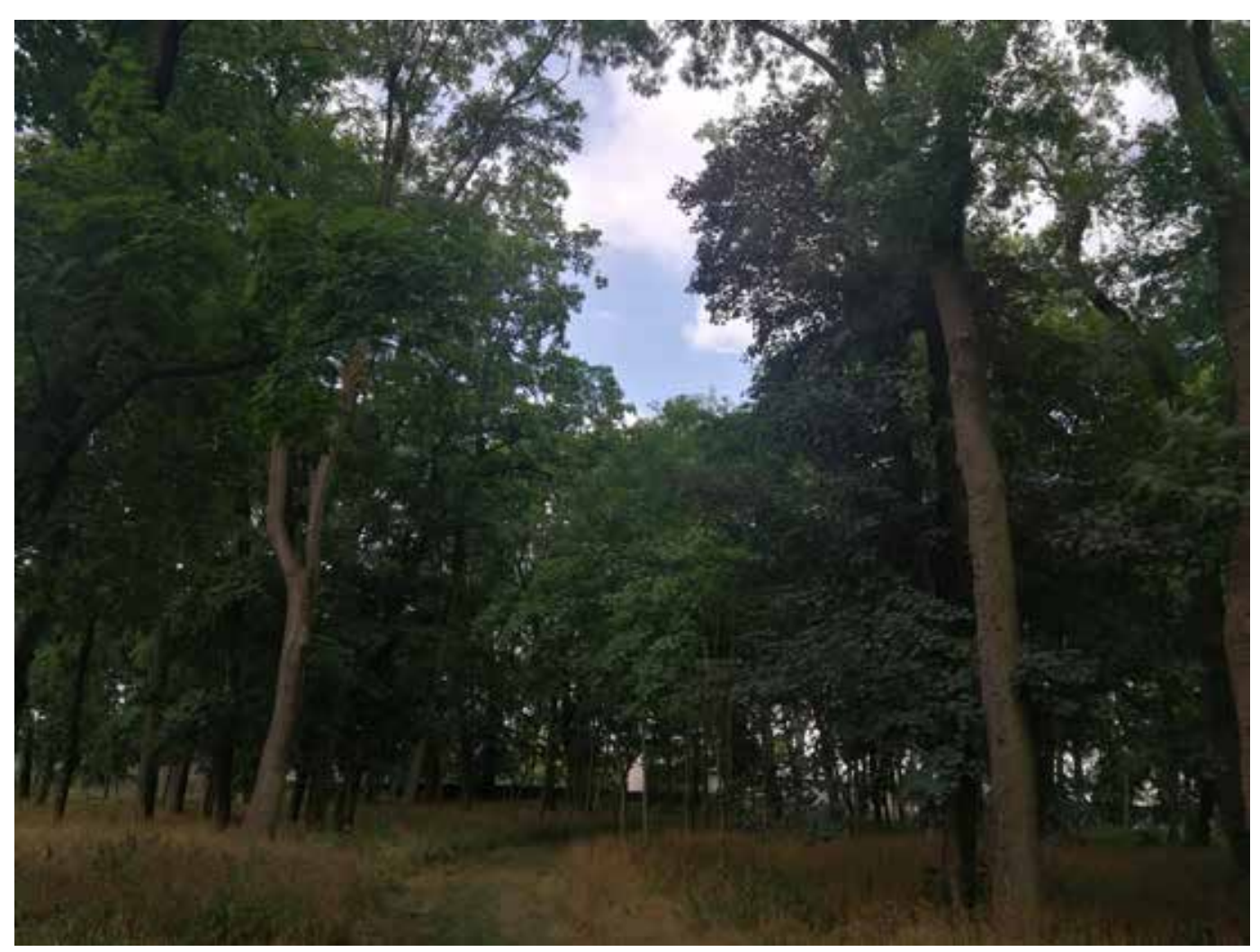

Pict. 2: Historical park in Wieniec around the Kronenbergs' Palace

Source: authors

\section{Culture-led regeneration - the local community perspective}

The changes that the PPC regeneration or revitalisation project is to achieve should give the estate a new life and restore it to its original splendour, but also address the expectations of the residents. It is especially important when the intention of the project is to make the PPC a cultural institution of supra-local influence. This new function can stimulate the development of the local community but the degree of success depends on whether its members are given a voice in decision-making processes so that the future use of the estate is harmonised with their expectations and needs. One instrument that allows the disappointment of the community to be avoided is an opinion survey.

According to the answers collected from respondents during the field survey in Wieniec, as many as $91.4 \%$ of them stated that they were interested in the future of the PPC, but only $32.8 \%$ actually knew the plans for its use. In the opinion of $81.0 \%$ of the surveyed villagers, the estate was very attractive both in terms of its architecture and the landscape. At the same time, some of them were of the opinion that it was of little value in its present state of repair.

The respondents frequently emphasised that the final use of the PPC was not important to them during interviews; they simply wanted to see it modernised and given some function to save it from further disrepair. Although several respondents referred to their bad memories of the place from the times it was used as a hospital, the majority $(75.9 \%)$ believed that its previous function would not discourage the village residents from visiting it. Consistent with 
this conviction was the distribution of answers to the question "Would the villager be interested in visiting the park for recreational purposes?", which was given an affirmative answer by as many as $91.4 \%$ of the respondents.

It is notable that the respondents perceived the PPC as having supra-local significance and consequently indicated that it should be accessible not only to the village residents, but most of all to people living across the region, and even in other areas of the country and abroad.

The key question the respondents were asked to answer was about the future use of the estate. To this end, they were requested to mark the uses they liked on a list with two groups of functions, namely "A cultural institution" (a concert hall, a library, a community cultural centre, a meeting place / club, a museum, a cinema / theatre) and "Other institutions" (a hotel, a restaurant, a kindergarten / nursery, an office, a medical care facility, a school). The respondents were given the option to indicate a use other than those shown on the list.

The analysis of the distribution of responses revealed that the majority of respondents chose a cultural function. As many as $67.2 \%$ of them believed that the place should be converted into a community cultural centre, with another $65.5 \%$ indicating a meeting place or a club. This finding was confirmed by residents' opinions expressed during interviews, who stated that the village community was poorly integrated (as a result of suburbanisation which caused a significant influx of ex-urban residents and spatial development weakening interpersonal relations) while indicating a scarcity of common spaces enabling the integration of the community.

Almost half of the respondents were interested in the palace being converted into a cinema or a theatre, although many of them observed that because of the proximity of Włocławek (the poviat city with approximately 110,000 inhabitants, providing the central functions for this area) this use was not a priority. Similar views were expressed regarding whether the palace might become a restaurant (because of a fast-food outlet operating near it), but it must be noted that this commercial function (unrelated to culture) was indicated by a relatively high number of respondents.

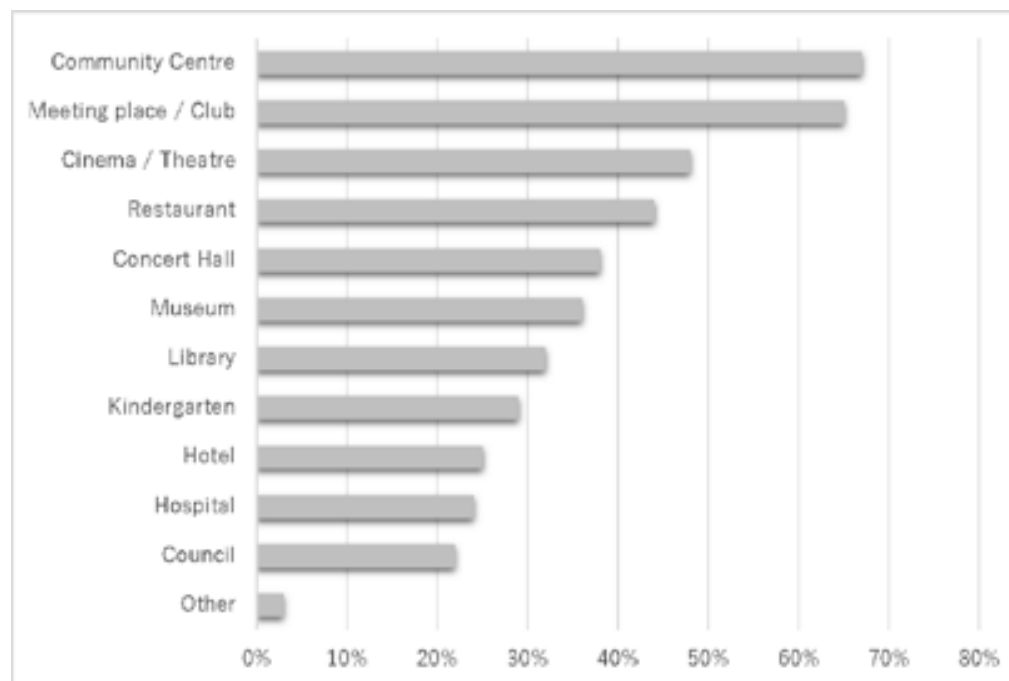

Fig. 3: The popularity of future uses for the PPC among respondents Source: developed by the authors based on the survey data 
S. Środa-Murawska et al.: Culture-led regeneration as a vital instrument for preserving the cultural heritage...

The uses that received fewer indications were, in a descending order, a concert hall, a museum (with many respondents stressing that the exhibition should relate to the local area, the history of the estate and its former owners), and a library.

About one in four respondents liked the idea of the palace being converted to a kindergarten or a nursery, with similar numbers favouring a hotel, a medical facility (preferably a hospital, because the village has a brand medical clinic), or a local office (the residents of Wieniec currently have to go to the office in Brześć Kujawski). Several respondents were of the opinion that the village needed a home for the elderly (e.g., a residential care home).

Many villagers (41\%), especially the elderly ones, still remembered the estate as a recreational area frequented by the residents. During the interviews, the aesthetic value of the garden, especially its well-kept flower beds and rose bushes, were referred to over and over again. Interestingly, $36 \%$ of respondents stated that local people were not allowed to visit the park. They remembered that its area had only been accessible to people who visited the hospital's patients. Regardless of the respondents' different memories about the accessibility of the park, they expressed keen interest in the PPC and concern for its condition. Almost all of them $(91 \%)$ were interested in what was going to happen to it, even though only one-third were knowledgeable about the plans regarding its use.

\section{Discussion}

The main types of activities delivered by the PPCs follow country-wide trends. The PPCs which are taken over by private companies are painstakingly renovated in cooperation with heritage conservation officers and used as extremely valuable and unique hotels and restaurants. A few PPCs have been divided by their private owners into two parts, one being used for residential purpose and the other being used as a space for cultural events (e.g., the "Dream Mansion" PPC with the Admiral's Chamber in Sielec). This trend exemplifies a sort of continuation of function. However, around one-third of PPCs are outside the trend. They are still used for educational purposes (schools, kindergartens) and as social welfare institutions (orphanages, care homes), as most of them were after they had been taken from private hands between the end of WWII and 1989. Because of the lack of interest from other parties, they are still held by local governments. A similar situation can be observed in the case of a large group of PPCs accommodating firms and companies providing services on behalf of farmers (consulting centres and breeding centres). Most of them emerged from the State Agricultural Farms that had operated in the PPCs between 1945 and 1989. Taken over and privatised, they still perform important functions for the development of agriculture. It is notable that many of those PPCs were not been renovated after 1989.

The results of the survey seem to indicate that the conversion of the palace in Wieniec for a cultural use adequately addressed the expectations of local residents and met with their approval. They appreciate the potential of the PPC and they consider its cultural function to be appropriate and protective of its value, and to raise its prestige.

Giving a supra-local cultural function to a PPC entails a fundamental change in its perception. This leads to a question about whether the culture-led regeneration of a rural PPC can result, as it has been observed in the case of urban heritage assets, in the establishment of "icon as PPC" similarly to "icon as building" proposed by Skot-Hansen et al. ${ }^{49}$

\footnotetext{
${ }^{49}$ SKOT-HANSEN, Dorte, RASMUSSEN, Casper Hvenegaard, JOCHUMSEN Henrik. The role of public libraries in culture-led urban regeneration. In: New Library World, Vol.114, No. 1/2, 2013, pp. 7-19.
} 
They define "icon as building" as:

- "different and unique;

- $\quad$ famous (or at least intended to be);

- of symbolic/aesthetic quality;

- $\quad$ part of urban branding". ${ }^{50}$

The PPCs analysed in the paper certainly meet the first three criteria. The architectural designs of the palaces in Wieniec, Lubostron, and Szafarnia and the unique layouts of greenery in them make them different and unique.

The PPCs in Szafarnia and Lubostron are already known across the region and probably countrywide. Given the scale and nature of renovation works in the PPC in Wieniec, and organisational efforts, it too will become recognisable soon.

The symbolic meaningfulness quality of PPCs is unquestionable. Moreover, considering that the analysed PPCs already are (or will be in the case of Wieniec) part of the branding of the rural areas around them, it can be assumed that culture-oriented PPCs have the potential to become "icon as PPC" at least on the regional scale.

The survey results imply that local communities perceive PPCs as a classic example of using icons to brand a place, and hope for the process to bring measurable benefits to them. For instance, the residents of Wieniec especially hoped to benefit from the recreational function of the park. One reason for this expectation was the lack of a common area that could perform a community integrating function (indicated by respondents in the village) and the high level of satisfaction of other needs.

One aspect that should not be missed is that communities perceive local PPCs as heritage elements defining their identity_-places that are associated with the history of the village and are present in their memories. The awareness of their value entails the realisation that these objects should be made available on a larger, supra-local scale. This leads to the establishment of cultural institutions on their grounds, such as libraries or cultural centres.

\section{Conclusions}

The analysis of the representative cases in the area of Kujawsko-Pomorskie Voivodeship confirms that culture-led regeneration is one of the best options for preserving the cultural heritage embodied in the PPCs. Particularly in rural areas, which are at risk of permanent marginalisation, appropriately renovated PPCs used for cultural functions meet the criteria put forward by Evans and Shaw. ${ }^{51}$ The revitalisation of PPCs is aimed at bringing their unique characteristics to light, and the cultural function they receive converts them into public spaces. The cultural function and accessibility to the public dramatically change the way they are perceived. A relevant illustration of such a change in perspective is the project in Wieniec which involves a thorough transformation of the neglected and dilapidated PPC, evoking negative associations because of its past as a hospital and then as an isolated, neglected, and abandoned place, into a vibrant cultural centre.

The use to which a PPC can be put largely depends on who owns it. Seventy years after nationalisation, most PPCs are readily accessible because they are still in public possession. They typically accommodate schools, NGOs, and various organisations. This allows for wide access to the PPC's resources. Unfortunately, because of funding shortages it is not possible

${ }^{50}$ SKOT-HANSEN et al., The role of public libraries...

${ }^{51}$ EVANS, SHAW, The Contribution... 
to save most of them from further dilapidation. In many cases, the parks are all that remain of them, whereas the palaces are long gone. The privately owned PPCs are usually used to deliver hospitality and recreational services, but their group of potential clients is limited to those who are very affluent.

Many of the PPCs which are held by the Treasury or local governments are converted into spaces for cultural activity to take advantage of their historical value. This function can be an illustration of culture-led rural regeneration. In this study, it was noted that the complexity of ownership relations, and the state of disrepair of PPCs in rural areas-requiring significant funding-restrict the possibility of undertaking renovation or repair works. Consequently, the factor guiding the restoration of PPCs held by the Treasury and local governments is culture, while private owners restore their properties with hospitality and restaurant services in mind.

The preferred function for the PPC in Wieniec is one related to culture. The villagers believe that it will act as a factor integrating the local community (representing a mixture of "old" residents and "new" residents who settled in the suburban area). Even though the estate was not accessible or only partially accessible for many years, residents are waiting for it to be open for all visitors. Understanding and appreciating the rank of the estate, they have no problem accepting the fact that they will not be its sole users. In fact, they appear to realise that the intended supra-local reach of their PPC is a confirmation of its value, originality, and uniqueness that they are proud of.

Because of the rising trend in cultural tourism and increasing interest in local identity, greater awareness and pressure can be expected throughout society on the preservation cultural heritage, historic greenery layouts.

The analysis of the historical parks in the Kujawsko-Pomorskie Voivodeship has shown their richness and high value, which is largely due to the fact that most of them have retained their original borders and layouts, including their water systems. It is also of importance to note that they have a huge (and still untapped) socio-economic potential. The mansions and palaces that have been preserved provide spaces for public services and private business, and the vast majority of parks are open to visitors.

Culture-led regeneration and the conversion of privately-held heritage assets to business uses (restaurants and hotels) appears to be the safest way to protect and preserve Poland's cultural heritage.

\section{Acknowledgement}

This article was created as part of the HICAPS project (Interreg Central Europe) financed by the European Regional Development Fund and the budget of Kujawsko-Pomorskie Voivodeship.

\section{References}

APP, Benjamin, BAUER, Judith, BOMBANA, Tiziano, BORGES, Marisa, OBERSCHMIDT, Anja (2003). The Palaces and Parks of Potsdam and Berlin, accessed 15 January 2020. http:/ / citeseerx.ist.psu.edu/viewdoc/download?doi=10.1.1.199.1622\&rep=rep1\&type=pdf 
BAŻANT, Dominik, BUDNICKA-KOSIOR, Joanna, GRZEGORZEWICZ, Ewelina, KACZMARSKI, Zdzisław, OLENDEREK Tomasz (2016). Parki wiejskie jako zasoby lokalne-badania stanu i zmian. In: Studia i Materiaty Centrum Edukacji Prayyrodniczo-Leśnej, 49B(5), pp. 54-60. ISSN: 1509-1414.

BENDIXEN, Peter (2001). Einführung in die Kultur- und Kunstökonomie. Wiesbaden: Springer. ISBN: 978-3-531-18279-7.

BRENNAN, Mark A., FLINT, Courtney G., LULOFF, A.E. (2009). Bringing together local culture and rural development: Findings from Ireland, Pennsylvania and Alaska. In: Sociologia Ruralis, 49(1), pp. 97-112. ISSN: 1467-9523.

CELIŃSKA, Elżbieta, GRUSZCZYŃSKA, Marianna (2001). Wieniec_zespół pałacowy. In: KUNIKOWSKI, S., ed. Materialy do driejón rezydencïi w Polsce, Kujawy W schodnie, Tom I, cæreść 2. Włocławek: Włocławskie Towarzystwo Naukowe, pp. 239-284. ISBN: 83-88115-35-9.

CHMIELNIK, Hanna (2013). Park zabytkowy w Lubostroniu rezydencji Skórzewskich na Pałukach. Lubostroń, Bydgoszcz: Eko-Park. ISBN: 978-83-7913-000-9.

DRAGAN, Weronika, DYMITROW, Mirek, KRZYSZTOFIK, Robert (2019). Between History, Politics and Economy: The Problematic Heritage of Former Border Railway Stations in Poland. In: Mitteilungen der Österreichischen Geographischen Gesellschaft, 161, pp. 229-250. ISSN: 0029-9138.

DUTKIEWICZ, Józef Edward (1964). Dwadzieścia lat ochrony zabytków w Polsce Ludowej. In: Ochrona Zabytków, 17(2), pp. 6-14. ISSN: 0029-8247.

DUXBURY, Nancy, CAMPBELL, Heather (2011). Developing and Revitalizing Rural Communities through Arts and Culture. A Literature Review. In: Small Cities Imprint, 3(1), pp. 111-122.

EVANS, Graeme, SHAW, Phyllida (2004). The Contribution of Culture to Regeneration in the UK: A Review of Evidence. A report to the Department for Culture, Media and Sport. London: London Metropolitan University.

FLORIDA, Richard (2004). The rise of the creative class and how it's transforming work, leisure, community and everyday life. New York: Basic Books. ISBN: 978-0465024773.

FORTUNA-ANTOSZKIEWICZ, Beata, GAW飞OWSKA, Agnieszka, ŁUKASZEWICZ, Jan, ROSŁON-SZERYŃSKA, Edyta (2012). Problemy rewaloryzacji i ochrony parków historycznych w centrum miasta na przykładzie Ogrodu Krasińskich w Warszawie. In: Technical Transactions. Architecture Issue, 109(6-A), pp. 145-166. ISSN: 2353-737X.

GANCARZ-ŻEBRACKA, Jadwiga (2013). Współczesne adaptacje historycznych założeń pałacowo-parkowych. Wybrane przykłady. In: Teka Komisji Architektury, Urbanistyki i Studiów Krajobrazonych, 9(2), pp. 32-42. ISSN: 1895-3980.

GUBAŃSKA, Renata (2008). Zagospodarowanie turystyczne założeń pałacowo-folwarcznych szansą aktywizacji dolnośląskiej wsi. In: Nauka Prayyroda Technologie, 2(4), Article No. 40. ISSN: $1897-7820$.

GUBAŃSKA, Renata (2014). Założenia rezydencjonalno-folwarcz̨ne na Dolnym Ślasku. Możliwości adaptacji do nowej funkecji. Wrocław: Wydawnictwo Uniwersytetu Przyrodniczego. ISBN: 97883-7717-194-3.

JANKOWSKI, Aleksander (2014). Pałac w Lubostroniu Fryderyka Skórzewskiego: pomnik rodowej dumy $i$ zamiłowania sztuk plastycznych. Bydgoszcz: Wydawnictwo Uniwersytetu Kazimierza Wielkiego. ISBN: 978-83-7096-949-3. 
S. Środa-Murawska et al.: Culture-led regeneration as a vital instrument for preserving the cultural heritage...

KAJA, Renata (2002). Przewodnik po zespołach pałacowych $i$ dworskich: walory przyrodniczoarchitektoniczne. Bydgoszcz: Wydawniczo-Promocyjna Agencja Duo-Press. ISBN: 978-8387419-76-9.

LANDRY, Charles (2012). The Creative City: A Toolkit for Urban Innovators. London: Routledge. ISBN: 978-1-84407-598-0.

LANE, Bernard (1994). What is rural tourism? In: Journal of Sustainable Tourism, 2(1-2), pp. 7-21. ISSN: 0966-9582.

LEWIS, David, BEBBINGTON, Anthony J., BATTERBURY, Simon P.J., SHAH, Alpa, OLSON, Elizabeth, SIDDIQI, M. Shameem, DUVALL, Sandra (2003). Practice, power and meaning: frameworks for studying organizational culture in multi-agency rural development projects. In: Journal of International Development, 15(5), pp. 541-557. ISSN: 0954-1748.

MCKAY, George (2005). Circular breathing: The cultural politics of jazz in Britain. Durham: Duke University Press. ISBN: 978-0-8223-8728-2.

MERTA-STASZCZAK, Adriana (2016). Rola gmin w zagospodarowaniu zabytkowych nieruchomości na Dolnym Śląsku. In: Ocbrona Zabytków, 2, pp. 191-217. ISSN: 0029-8247.

MURZYN-KUPISZ, Monika (2010). Wpływ przedsięwzięć związanych z odnową obiektów i miejsc zabytkowych na gospodarkę lokalną i regionalną. In: Ochrona Zabytków, 1-4, pp. 139-156. ISSN: 0029-8247.

Narodowy Instytut Dziedzictwa (NID) (2017). Raport o stanie zachowania zabytków nieruchomych w Polsce. Zabytki wpisane do rejestru zabytków (ksiegi rejestru A i C). Warszawa: Narodowy Instytut Dziedzictwa. ISBN: 978-83-63260-93-4.

NASH, Robert, MARTIN, Andrew (2003). Tourism in peripheral areas - the challenges for northeast Scotland. In: International Journal of Tourism Research, 5(3), pp. 161-181. ISSN: 1099-2340.

NURYANTI, Wiendu (1996). Heritage and postmodern tourism. In: Annals of Tourism Research, 23(2), pp. 249-260. ISSN: 0160-7383.

PANELLI, Ruth (2002). Young rural lives: strategies beyond diversity. In: Journal of Rural Studies, 18(2), pp. 113-122. ISSN: 0743-0167.

PAWLIKOWSKA-PIECHOTKA, Anna (2001). Nieruchomość zabytkowa jako lokata kapitału: motywacje inwestorów. In: Ocbrona Zabytków, 54(2), pp. 133-142. ISSN: 0029-8247.

RICHARDS, Greg (1996). Cultural Tourism in Europe. Oxon: CAB International. ISBN: 9780851991047.

ROBERTS, Lesley, HALL, Derek (2004). Consuming the countryside: Marketing for 'rural tourism'. In: Journal of Vacation Marketing, 10(3), pp. 253-263. ISSN: 1356-7667.

RZESZOTARSKA-PAŁKA, Magdalena (2016). Threats of palaces and manors-garden ensembles on the area of West Pomerania connected with structural transformations of rural areas in 20th and 21st century. In: Technical Transactions. Architecture Issue, 5-A(5), pp. 225-237. ISSN: 2353-737X.

SHARPLEY, Richard, ROBERTS, Lesley (2004). Rural tourism - 10 years on. In: International Journal of Tourism Research, 6(3), pp. 119-124. ISSN: 1099-2340.

SKOT-HANSEN, Dorte, RASMUSSEN, Casper Hvenegaard, JOCHUMSEN, Henrik (2013). The role of public libraries in culture-led urban regeneration. In: New Library World, 114(1/2), pp. 7-19. ISSN: 0307-4803. 
SLAMA, Kay (2004). Rural Culture is a Diversity Issue. In: Minnesota Psychologist, 53(1), pp. 9-13. SMALLEY, K. Bryant, WARREN, Jacob C. (2012). Rurality as a diversity issue. In: SMALLEY, K. Bryant, WARREN, Jacob C., RAINER Jackson P. (eds.). Rural mental health: Issues, policies, and best practices. New York: Springer Publishing Company, pp. 37-47. ISBN: 9780826107992.

SMITH, Larry W., Jr. (2011). Urban indigenous culture in Los Angeles County. California: California State University, Long Beach. ISBN: 9781124858050.

SOLDANI, Alberto, JANKOWSKI, Dariusz (2004). Zabytki. Ochrona i opieka. Praktyczny komentarz do nowej ustawy. Tekst Ustawy z dnia 23 lipca 2003 r. Zielona Góra: ZCO. ISBN: 8388673-76-9.

STRASZAK-CHANDOHA, Sylwia (2010). Polityczno-ekonomiczne uwarunkowania sytuacji rolnictwa w PRL. In: CHUMIŃSKI, Jędrzej, ed. Modernizacja ç̧y pozorna modernizacja. Społeczno-ekonomiczny bilans PRL 1944-1989. Wrocław: Gajt, pp. 362-398. ISBN: 978-838817-892-4.

SU, Ming Ming, WALL, Geoffrey (2015). Exploring the shared use of world heritage sites: Residents and domestic tourists' use and perceptions of the summer palace in Beijing. In: International Journal of Tourism Research, 17(6), pp. 591-601. ISSN: 1099-2340.

ŚRODA-MURAWSKA, Stefania (2019). Rozwój oparty na sektorže kultury-doświadczenia średnich miast w Polsce. Torun: Wydawnictwo Naukowe Uniwersytetu Mikołaja Kopernika w Toruniu. ISBN: 978-83-231-4278-2.

ŚRODA-MURAWSKA, Stefania (2020). Railway feat. Culture-Rumia library effect as an example of the influence of culture-led regeneration in a medium-sized city in Poland. In: Cities, 106. ISSN: 0264-2751.

ŚRODA-MURAWSKA, Stefania, BIEGAŃSKA, Jadwiga, DAૃBROWSKI, Leszek (2017). Perception of the role of culture in the development of small cities by local governments in the context of strategic documents-a case study of Poland. In: Bulletin of Geography. Socioeconomic Series, 38, 2017, pp. 119-129. ISSN: 1732-4254.

THROSBY, David (2001). Economics and Culture. Cambridge: Cambridge University Press. ISBN: 978-0521586399.

TIŠLIAR, Pavol, KAČÍREK, Luboš, JANTO, Juraj (2020). History and memory of hospital sites. On the example of the "old" hospital in Topol’čany. In: Muzeológia a kulturne dedičstvo, 8(1), pp. 31-45. ISSN: 1339-2204.

VON ROHRSCHEIDT, Armin Mikos (2008). Turystyka kulturowa: fenomen, potencjat, perspektywy. Gniezno: GWSHM Milenium. ISBN: 978-83-61352-00-6.

ŻOR, Andrzej (2011). Kronenberg. Drieje fortuny. Warszawa: Wydawnictwo Naukowe PWN. ISBN: 978-83-011-6739-4.

\section{Internet sources}

Interreg-Central Europe. Work package T3-Revitalization concepts and test of outputs on pilot sites, accessed 15 January 2020.

https:/ /www.interreg-central.eu/Content.Node/WPT3.htm

Szafarnia. History, accessed 15 January 2020.

http://www.szafarnia.art.pl/en/historia/ 